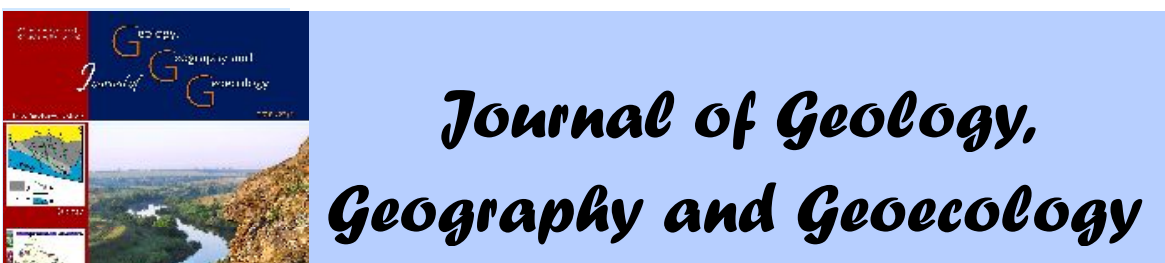

Journal home page: geology-dnu-dp.ua

\title{
Geochemical aspect of landscape planning in forestry
}

\author{
N. V. Maksymenko ${ }^{1}$, V. O. Voronin ${ }^{1}$, N. I. Cherkashyna ${ }^{1}$, S. P. Sonko ${ }^{2}$ \\ ${ }^{l}$ V. N. Karazin Kharkiv National, Kharkiv, Ukraine, e-mail: nadezdav08@gmail.com \\ ${ }^{2}$ Uman National University of Horticulture, Uman, Cherkasy region, Ukraine, e-mail: sp.sonko@gmail.com
}

\section{Received 30.04.2018;}

Received in revised form 15.05.2018; Accepted 05.06.2018

Abstract. One of the modern methods of spatially estimating anthropogenic impact on a given territory is landscape planning, including the stage of assessment of the conditions of a natural complex . The results of such an evaluation are used in environmental management. The aim of the work is to assess the ecological conditions of the Vasyshchivsky forest area by means of landscape and environmental planning. The aim is achieved by performing the following stages of work: assessment of the distribution and intensity of contamination sources in the Vasyshchivsky forest area; drawing a scheme showing parts of the territory with probable conflicts; making a soil and geochemical survey of the forest area to assess acidity distribution and total content of carbonates in the soil as the consequences of pollution of the forest ecosystem ; specification of geochemical characteristics of soils on the forest sites in the established location of former fires; forecast of limits of afte-r fire areas based on the analysis of cartographic works developed by the authors. The geochemical characteristics of the soils in Vasyshchivsky forest have been studied to identify the areas affected by fire, and the results of this study are given in this paper. During the inventory phase of landscape and environmental planning, a complete survey of the forest territory was conducted and a landscape map was drawn. Based on the authors' matrices filled with conflicts of natural use, the areas with low, medium and high levels of conflict have been marked within the study area. Landscape and environmental planning has been evaluated by soil sampling outside the test points on the network and their laboratory analysis. The results of the evaluation phase were maps illustrating the geochemical situation in the forest soil cover. The article presents cartographic models of the spatial distribution of carbonates in the forest soils, water and salt extraction $\mathrm{pH}$. The results of the study are part of an environmental assessment of Vasyshchivsky forest area. In future they will be used in restoration of the forest ecosystems after fire.

Key words: forestry, landscape, nature, landscape and environmental planning, geochemical aspect, soils.

\section{еохімічний спект л ндш фтного пл нув ння території лісництв}

\author{
• • ксименко ${ }^{1}$, • о оронін ${ }^{1}$, . ерк шин ${ }^{1}$, . . онько \\ рківський н ціон льний університет імені . . $\quad$ р зін, рків, кр їн, е-mail: nadezdav08@gmail.com \\ 2 м нський н ціон льний університет с дівництв, мнь, ерк ськ обл сть, кр їн, e-mail: sp.sonko@gmail.com
}

нот ція. ослідження сищівського лісництв здійснене н основі вторської методики л ндш фтно-екологічного пл нув ння територій різного функціон льного призн чення. меж х інвент риз ційного ет пу л ндш фтно-екологічного пл нув ння проведено суцільне обстеження території лісництв т скл дено л ндш фтну к рту. основі з повнених втор ми м триць конфліктів природокористув ння в меж х лісництв виділено території з низьким, середнім і високим рівнем конфліктів. ціночний ет п л ндш фтно-екологічного пл нув ння ре лізов но шляхом відбору зр зків грунту з мережею тестових точок т їх л бор торним н лізом. езульт том оціночного ет пу ст ли к ртогр фічні твори, що ілюструють геохімічну ситу цію в грунтовому покриві лісництв . ст тті н ведено к ртогр фічні моделі просторового розподілу к рбон тів у грунт х лісництв , p водної т сольової витяжки. езульт ти дослідження ст новлять скл дову екологічної оцінки території сищівського лісництв для под льшого розроблення н прямків оптиміз ції природокористув ння в ньому.

лючові слов : лісництво, л ндш фт, природокористув ння, л ндш фтно-екологічне пл нув ння, геохімічний спект, конфлікт природокористув ння, грунти

Introduction. Today, forests in suburban areas are used as a recreational resource (Stolberg, 2000). This is especially true in summer, when people adversely affect he ecological conditions of the forest ecosystem and its associated biodiversity (Kucheriavyj, 2001). In Ukraine forests are not private property, so 
anybody can go there. According to the State Emergency Service (cite, 2016), there were 941 fires in the forest fund of Ukraine in 2016. The total burnt area was 1,101 hectares. The main reason for the occurrence of forest fires is the violation of the fire safety rules in the forests by visitors and local inhabitants. Here we use several methodological approaches, including chemical ones, to evaluate the degree of adverse human impact on forest ecosystems.

An assessment of the ecological conditions of soils is among the most important factors in evaluating the conditions of an entire ecosystem. A forest ecosystem is no exception, which is why modern ecologists pay special attention to the environmental analysis of soils.

The background content of trace elements and other chemical characteristics of soils in Ukraine have been investigated in detail by Nosko, 1975 at the O.N. Sokolovsky NSC "Institute for Soil Science and Agricultural Chemistry" NAAS of Ukraine. Moreover, the chemistry of soil processes in the forests has been studied by Armson, 1977, Johnson \& Curtis, 2001, Perry, 1994, Gospodarenko, 2015 and Majorova \& al., 2011.

Another area of soil research is the study of geochemical consequences of fires. The impact of fires on the rate of ecosystem recovery was studied by Chandler \& al., 1983, DeBano \& al., 1976, Raison, \& al., 1985, St. John \& Rundel, 1976, Tiedemann, 1987 Valendik \& al., 2006, Anuchin, 1982, Rabotnov, 1978, Rodin \& al., 1968, Sannikova, 1977 and other researchers. Having examined the carbonate soil profile, Dajneko \& al., 1995 has concluded that the distribution of carbonates is affected by the thermal regime, a rise in temperature leads to an increase in carbon dioxide and concentration of carbonates.

Previous research has outlined a possible range of further study of dependence of soils chemistry on the environmental conditions of a forest as a whole and as a result of fires, in particular.
One of the modern methods of spatially estimating anthropogenic impact on a given territory is landscape planning, including the stage of assessment of the conditions of a the natural complex . Evaluation results are used in the environmental management. The methodology developed by European scientists (Landschafts Planung, 2014., Auhagen \& al. 2002, Von Haaren \& al. 2008) is successfully used in different countries and is recognized as a mandatory procedure at the national level. In contrast, Ukraine has no legal basis for this (cf., Maksymenko \& Cherkashina 2013). To overcome this, we suggest applying the methods of landscape planning for territories with different uses of nature : urban, agricultural and forest landscapes, (Maksymenko, 2014, Maksymenko \& Klieshch, 2017). This study has covered the evaluation stage.

The aim of the work is to assess the ecological conditions of the Vasyshchivsky forest area by means of landscape and environmental planning.

The aim is achieved by performing the following stages of work:

- Assessment of the distribution and intensity of contamination sources of the Vasyshchivsky forest area;

- Drawing a scheme showing parts of the territory with probable conflicts;

- Soil and geochemical survey of the forest area to assess acidity distribution and total content of carbonates in the soil as the consequences of pollution of the forest ecosystem ;

-Specification of geochemical characteristics of soils on the forest sites in the established location of former fires;

- Forecast of limits of after- fire areas based on the analysis of cartographic works developed by the authors.

\section{Material and Methods.}

The Vasyshchivsky forest area is located to the south of the city of Kharkiv (Figure 1) (N49 $49^{\prime}$, E36 $\left.{ }^{\circ} 1^{\prime}\right)$. It includes 27 Forest patterns.

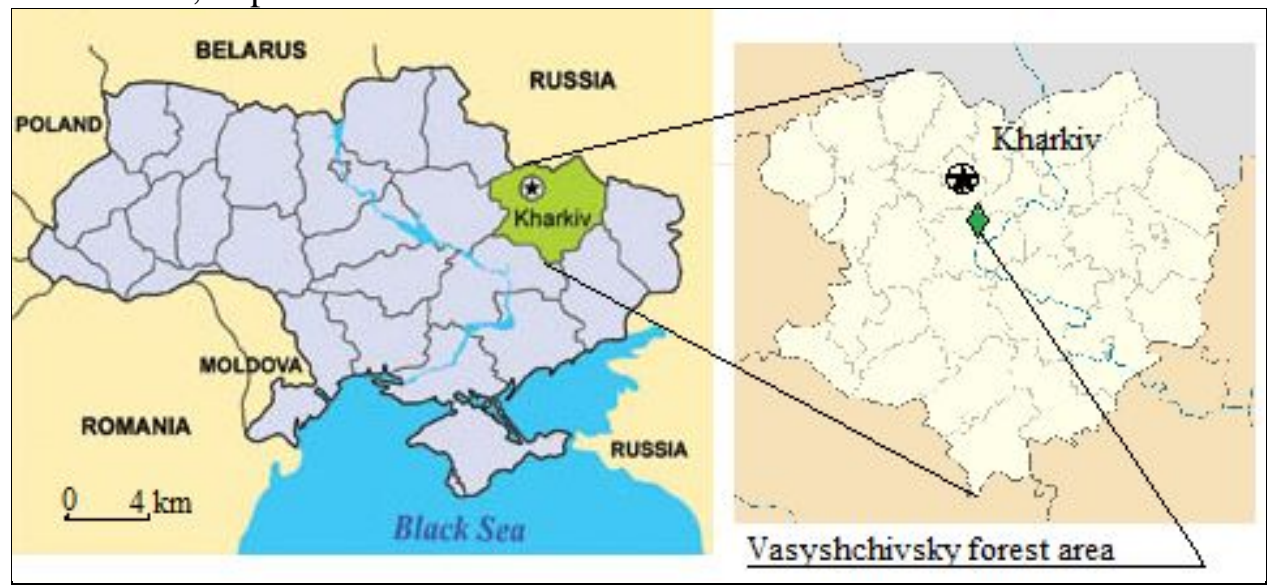

Fig 1. Geographical location of Vasyshchivsky forest area 
We have selected the Forest pattern "Bir II" as a research object because it is the most representative in this forest.

Two tree species dominate on the territory of Vasyshchivsky forest - Quercus robur L. and Pinus sylvestris $L$. The Quercus robur $L$. is predominantly found in the watersheds and hilly areas, whereas the common Pinus sylvestris $L$. is on the floodplain terraces. There are also areas where the following species are predominant: Alnus glutinosa Gaertn, Salix alba L., Salix fragilis L., Betula pendula, Tilia cordata Mill and Populus deltoides Moench.

In the more elevated areas and in the watersheds you can also find Fraxinus excelsior L., Acer campestre L., less often - Quercus borealis Michx, Picea abies Karst and Populus alba L. In the Forest pattern "Bir II", the correlation between tree species is the most similar to the average correlation throughout the whole Vasyshchivsky forest area. Therefore, it can be considered representative for this territory.

As part of the initial inventory phase of landscape planning, we created a large scale landscape map of Forest pattern "Bir II" (based on digitized topographic map sheets 1:10 000, satellite images Forest pattern "Bir II", as well as the materials of fieldwork using GPS-shooting). The map shows nature use conflicts; their intensity has been defined by the authors' own methods outlined in the work by Maksymenko \& Koresheva, 2014.

Soil sampling was conducted between June and September 2014 for geochemical research on the forest, both on Forest pattern "Bir II", and beyond its boundaries - in landscape areas adjacent to the forest. In this area the soil sampling was carried out on the basis of a planned network of uniform increments of $500 \mathrm{~m}$ by digging. The scheme for soil sampling is shown in Figure 2. Samples were selected by an envelope method (5 samples on each test section) in accordance with the existing guidelines and standards - GOST 17.4.3.01-83 GOST 17.4.4.02-84, ISO 4287: 2004. Samples were taken at 0-10 cm, 10-20 $\mathrm{cm}$ and $20-30 \mathrm{~cm}$ depths; afterwards soil samples from different depths were mixed. Thus, the surface layer of soil was analyzed and evaluated. In total, during the fieldwork 200 mixed soil samples were selected ( 5 from each of the 40 test sites).

Chemical analysis of samples was performed in the laboratory of Analytical Environmental Research, V. N. Karazin Kharkiv National University. To assess the alkaline-acid conditions of elements migration, we measured $\mathrm{pH}$ of water and salt extract of soil and determined the index of anionic composition - bicarbonate ions content.

Treatment of empirical material was carried out by methods of mathematical statistics (software Statistica 6.0, Microsoft Excel) (ANOVA). For example, ANOVA study of differences in $\mathrm{pH}$ of water extract of the soil (the dependent variable) by samples location (independent variable).

To establish the nature of the spatial distribution of the studied parameters, the obtained results were interpolated by the Natural Neighbour method in GIS environment.



\section{Legend}

- Sample locations Vasyschivsky forestry

Telling locations 126. Number of road blocks: roud:

with hard cover - forest cover landscapes:

— residential

— industrial

forestry

water

agricultural

Fig. 2. Soil samples location in the Vasyshchivsky forest area 


\section{Results}

The exposure of forest to anthropogenic stress gives rise to conflicting uses of the landscape (fires, transport pollution, pollution from adjacent territories, logging) (Landschafts Planung, 2014, Kolbovskij 2008, Maksymenko, 2014, Maksymenko \&
Koresheva, 20142014). A conflict is understood as the load on the environment at a certain intensity. The conflicts on the territory adjacent to the Vasyshchivsky forest area are derived from man-made landscapes (Figure 3): agricultural, residential, linearroad, forest ones.

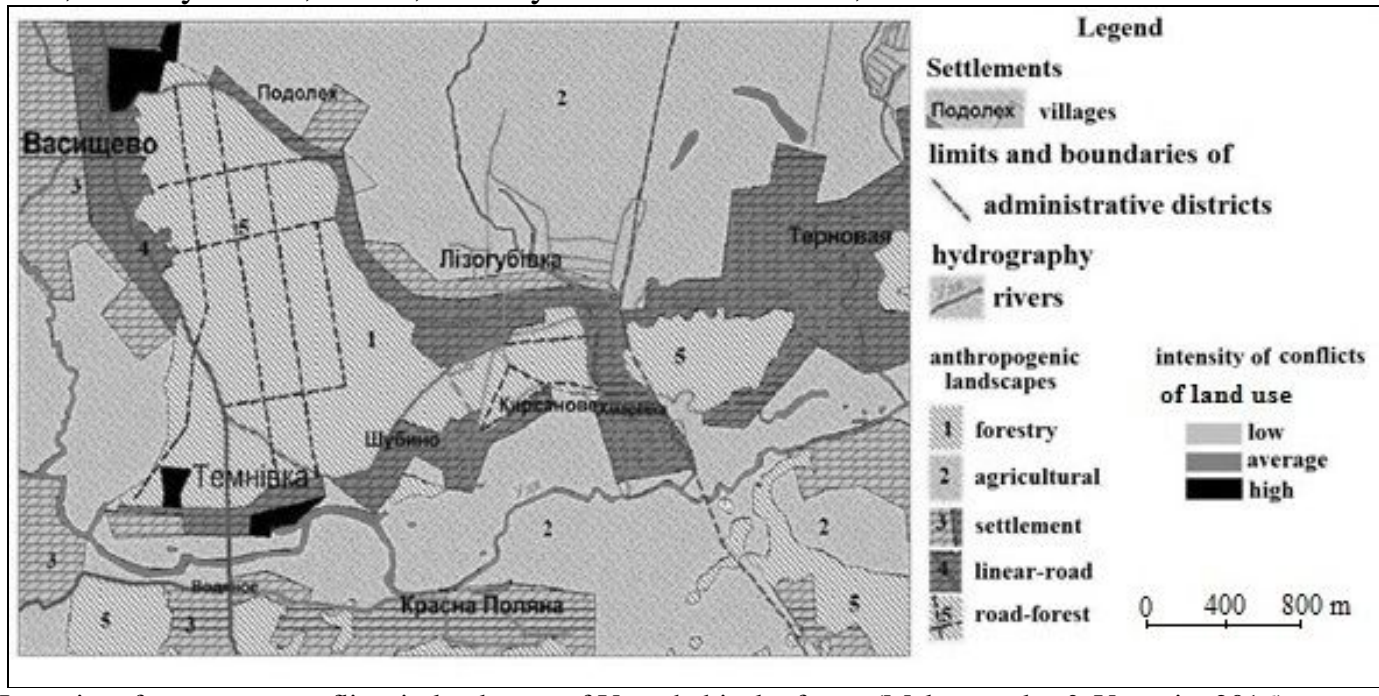

Fig. 3. Intensity of nature use conflicts in landscape of Vasyshchivsky forest (Maksymenko \& Voronin, 2016)

To organize conflicts there is a convenient matrix form. One of its axes is the types of nature use, which "harm" nature, the second axis is the "damaged" landscapes; it is advisable to show the conflicts' characteristics in the cells of the matrix.

For the convenience of further interpretation of the results, all the conflicts' characteristics, (intensity, impact time, dynamics) are displayed in the table in the form of indexes, assigning the lowest level index 1, and increasing the index as the indicator grows. The intensity is indicated as follows: 1 - low, 2 - medium, 3 - high. After completing the matrix, the sum of points for each landscape in each particular area has been determined. The higher the sum of points is, the higher the level of conflict is. Further quantitative indicators find their spatial interpretation on the map, where using plane characters the zones of conflict are displayed

The enclosed map (Figure 3) shows the highest level of conflicts in areas where the forest borders on agricultural landscapes.

When fertilizers are used, soil as well as drinking water quality in an agricultural environment deteriorates. Groundwater carries excess of trace elements accumulated in the soil, changing the concentration of carbonates and $\mathrm{pH}$ levels of the soil. Residential landscapes also have an adverse effect on the geochemistry of the soil, because all human activities (buildings) have negative effects on the migration paths of trace elements. Buildings create artificial geochemical barriers. Line-roads and forest roads worsen air quality (engine exhaust fumes) and compact the soil - which is also a barrier to the migration of trace elements.

A forestry landscape is a natural complex, which does not bear anthropogenic pressure, but is contaminated only by adjacent areas; the burden on forestry is heavier in the points where there are a number of environmental changes. Thus, we have selected three degrees of intensity of nature conflicts (Figure 3): low, medium, high.

Low intensity conflicts include only 1-2 adjacent areas of different designation that affect the environmental conditions. Average 2-3, high $>3$. The Vasyshchivsky forest shows high intensity conflicts in most of the areas, mainly in residential landscape locations (Figure 3), while there is an average impact on the forest areas surrounding the landscape.

The laboratory analysis showed that within the study area the content of carbonates was mainly on a low $(0.01 \%)$ level of (Figure 4$)$. A higher level of carbonates was observed in areas with anthropogenic activity. Residential landscape adjacent to the forest (Figure 3) experienced anthropogenic load. In such places the level increased to $0.521 \%$. The $\mathrm{pH}$ levels of water (Figure 5) and salt (Figure 6) extracts showed that soils are predominantly weakly acidic and acidic, but on the edge of residential landscapes there was an increase in the $\mathrm{pH}$ level. Based on the distribution of carbonates level and $\mathrm{pH}$ of the environment, it can be assumed that there were forest fires in blocks 112, 102, 98, 94 (Figure 2). 


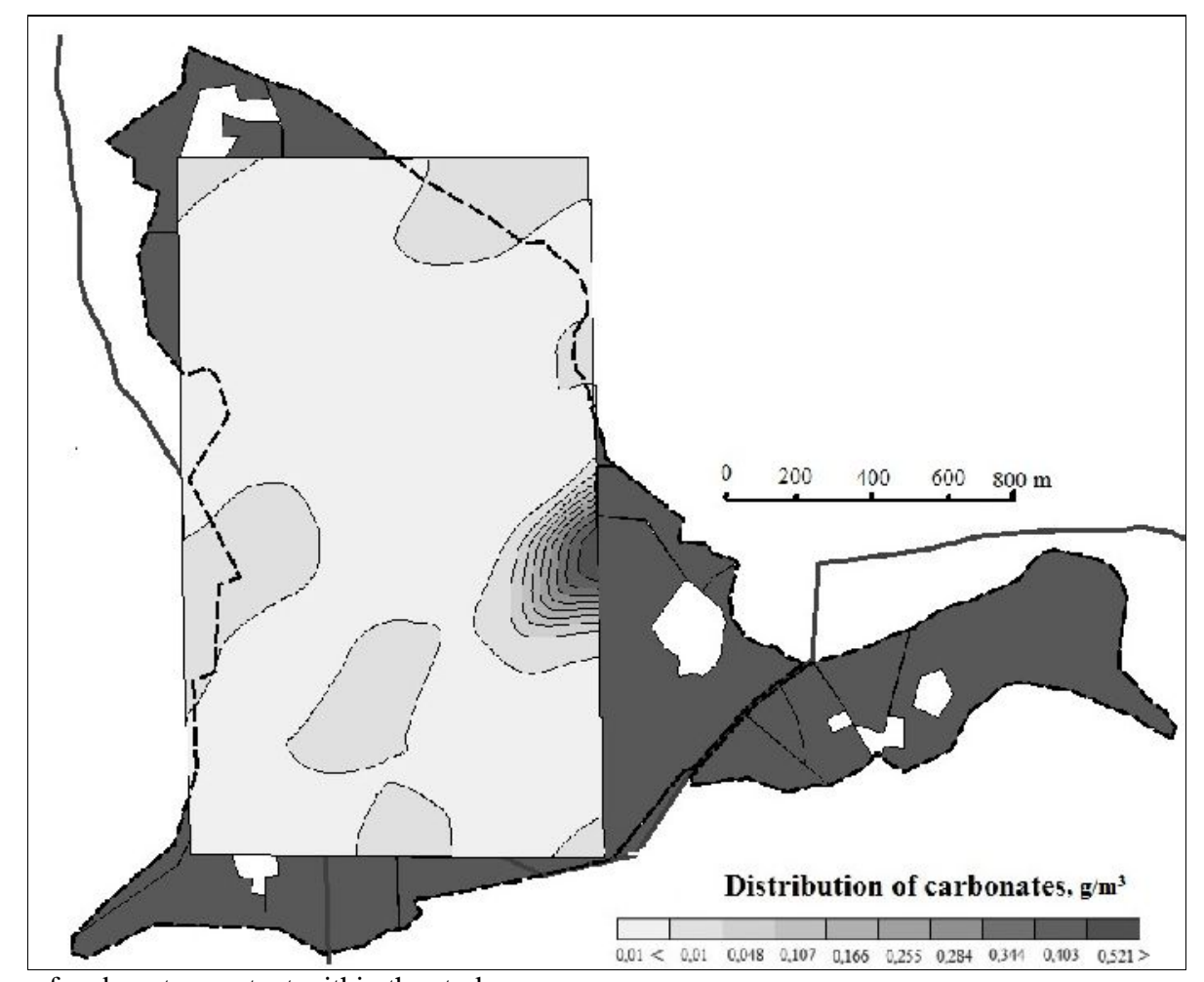

Fig. 4. Distribution of carbonates content within the study area

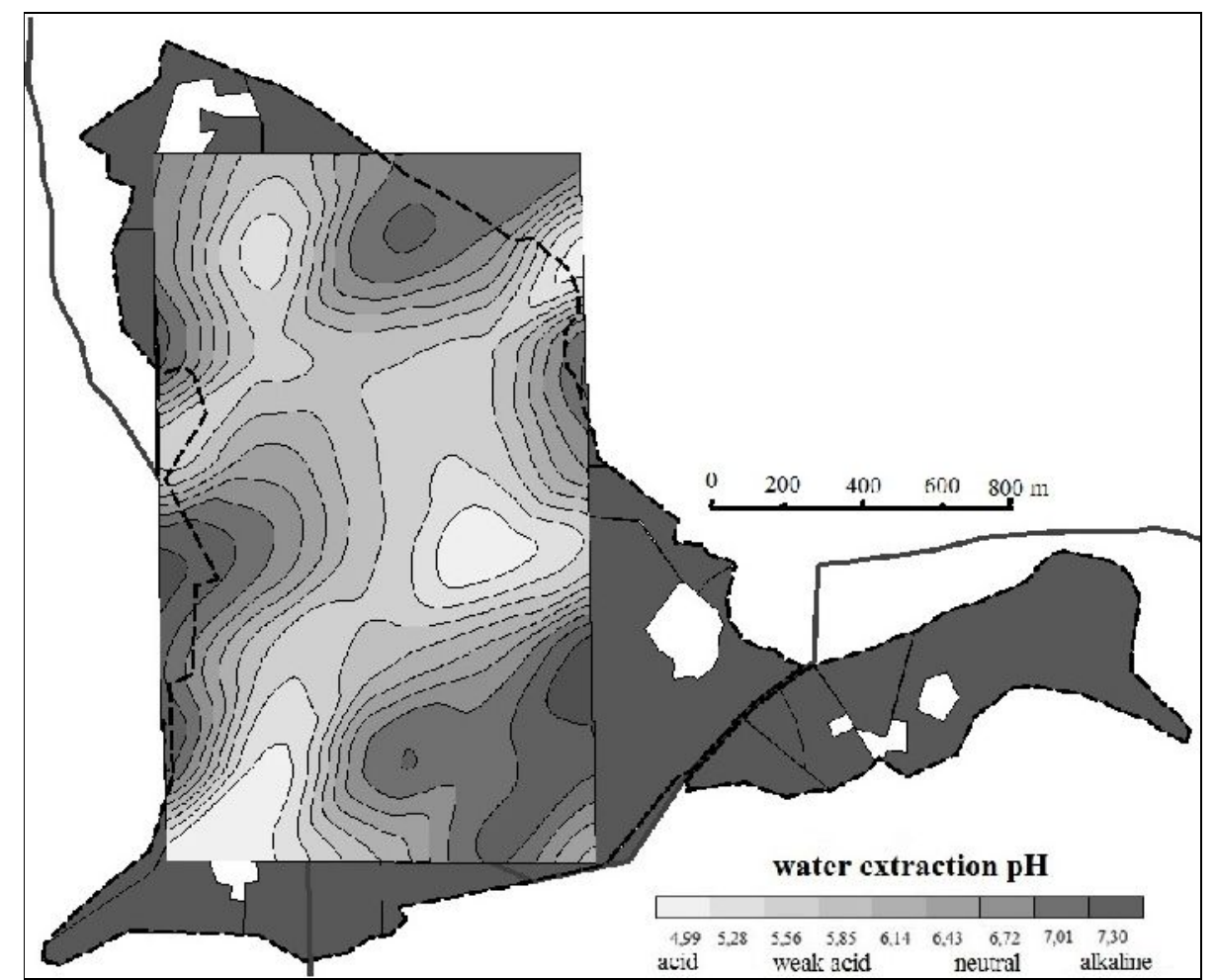

Fig. 5. Distribution of water extraction $\mathrm{pH}$ within the study area 




Fig. 6. Distribution of salt extraction $\mathrm{pH}$ within the study area

\section{Discussion}

The majority of the studied soils (for samples from depths of $0-30 \mathrm{~cm}$ ) had reactions varying from weakly acid to slightly alkaline (Figure 5,6 ). The surface layer of the forest soil had quite a large range of $\mathrm{pH}_{\mathrm{H} 2 \mathrm{O}}$ amplitude - from 5.1 to 7.8. The average $\mathrm{pH}_{\mathrm{H} 2 \mathrm{O}}$ of the soil on Forest pattern "Bir II" is 6.51 . Standard deviation is -0.77 , variance - 0.74. $\mathrm{p} \mathrm{Cl}$ amplitude range is from 4.18 to 6.92 . Average $\mathrm{p} \mathrm{Cl}$ of the studied soil on Forest pattern Bir II is 5.57. Standard deviation is -0.77 , variance -0.76 . In automorphic soil $\mathrm{pH}$ of ground water extraction is primarily caused by the content of $\mathrm{Ca}^{2+}$ and ${ }^{3-}$. In hydromorphic soils influence of water-soluble salts on $\mathrm{pH}$ is not as clear, and unlike automorphic soils, $\mathrm{Cl}^{-}$and $\mathrm{Mg}^{2+}$ ions play a more important role. The inverse relationship between water-soluble calcium carbonate content and $\mathrm{pH}$ is observed in meadow soils of the floodplain, which is constantly fueled by capillary moisture almost to the surface due to the proximity of groundwater. The maximum, in general for the landscape, amount of water soluble carbonates in the top layer of soil is due to their deposition on a steamy barrier.

The obtained $\mathrm{p}_{2}$ and $\mathrm{p} \quad 1$ values indicate widespread alkalization of soils in areas with high anthropogenic load, which in most cases is caused by the presence of carbonates of alkali and alkaline earth metals. The area of soil alkalization is mainly localized in the periphery of the study area - in places with a very high level of nature use conflicts.

\section{Conclusions}

Chemical study of the selected samples made it possible to identify the related conflicts in the areas adjacent to the forest. Thus, the study on the carbonates content of the area has shown increased levels of carbonates in places of local anthropogenic load, which indicates negative human impact on the environment. In general, carbonate composition is uniform, but it increases in landscapes with high levels of conflicts.

Soil $\mathrm{pH}$ level depends both on the meteorological factors that make soils acidic, and the conditions of the forest floor formation. The study has found a pattern of decrease in acidity levels with an increase in anthropogenic load, i.e. soil alkalinity increases in landscapes with high nature use conflicts.

\section{References}

Armson, K.A., 1977. Forest Soils: Properties and Processes, University of Toronto Press, 390.

Auhagen, A., Ermer, K., Mohrmann, R., 2002. Landschaftsplanung in der Praxis. Ulmer Verlag, Stuttgart, 416.

Chandler, C., Cheney, P., Thomas, P., Trabaud, L.Williams, D., 1983. Fire in forestry. Vol. 1: forest fire behavior and effects. New York: John Wiley \& Sons, 450.

DeBano, L.F., Savage, S.M. and Hamilton, D.A., 1976. The transfer of heat and hydrophobic substances during burning. Soil Science Society of America Journal. 40, 779-782.

Grier, C.C., 1975. Wildfire effects on nutrient distribution and leaching in a coniferous ecosystem. Canadian Journal of Forest Research. 5, 559-607. 
Johnson, D., and Curtis, D., 2001. Effects of forest management on soil $\mathrm{C}$ and $\mathrm{N}$ storage: metaanalysis. Forest Ecology and Management, 227-238.

Landschafts Planung, 2014. Mit Beitr. von: Claus Bittner. Christina von Haaren (Hrsg.). Stuttgart: UTB, Ulmer, 527.

Maksymenko, N., Cherkashina, N., 2013. Prospects of landscape planning in legislation of Ukraine // Acta envinronmentalica universitatis comenianae. - Bratislava: Univerzita Komenského v Bratislave, Vol. 21 (1), 83-88.

Perry, D., 1994. Forest Ecosystems. First Edition. The Johns Hopkins University Press.

Raison, R.J., Khanna, P.K., Woods, P.V., 1985. Mechanisms of element transfer to the atmosphere during vegetation fires. Canadian Journal of Forest Research. 15, 132-140.

St. John, T.V., Rundel, P.W., 1976. The role of fire as a mineralizing agent in a Sierran coniferous forest. Ecologia. 25, 35-45.

Tiedemann, A.R., 1987. Combustion losses of sulfur and forest foliage and litter. Forest Science. 33, 216223.

Vlamis, J., Biswell, H. H., Shultz, A. M., 1955. Effects of prescribed burning on soil fertility in second growth ponderosa pine. Journal of Forestry. 53, 905-909.

Von Haaren, C., Galler, C., Ott S., 2008. Landscape planning. The basis of sustainable landscape development Gebr. Klingenberg Buchkunst Leipzig GmbH, 52.

Anuchin, N.P., 1982. Lesnaja taksacija [Forest taxation]. Moskva: Lesn. prom-st. 550. (in Russian).

Valendik, E.N., Sukhinin, A.I., Kosov, I.V., 2006. Vlijanie nizovyh pozharov na ustojchivost' hvojnih porod [Influence of ground fires on the stability of softwood]. Krasnoyarsk: SB RAS IL them. Sukacheva. 96 (in Russian).

Gospodarenko, G.M., 2015. Agrohimija: Pidruchnik [Agrochemistry: Textbook]. 372 (in Ukranian).

Daineko, E.K., Olikova, I.S., Sycheva, S.A., 1995. Karbonatnyj profil celinnyh chernozemov [Carbonate profile of virgin chernozems]. Geografija i prirodnye resursy [Geography and natural resources]. 98 (in Russian).

cite web |url=http://www.dsns.gov.ua/files/2017 /2 /22/2016.pdf/ |title=REPORT on the main results of the State emergency service of Ukraine in 2016 |date $=25$ february 2017 | (in Ukranian).

Kolbovskiy, E., 2008. Landshaftnoye planirovaniye: uchebnoye posobiye dlya studentov vysshikh uchebnykh zavedeniy [Landscape planning: a textbook for university students]. Moskva: Izdatel'skiy tsentr «Akademiya». 38-69. (in Russian).

Kucheriavyj, V.P., 2001. Urboekologija : pidruchnik [Urboecology. Textbook]. L'viv. 440 (in Ukranian).

Mayorova, O.Y., Voityuk, V.B., Grytsak, L.R., 2011. Vmist dejakih makro-i mikroelementiv u gruntah ta roslynah Gentiana lutea L. z dvoh Chornogirs'kih populjacij Ukrajins'kih Karpat [The content of some macro- and microelements in soils and plants Gentiana lutea L. from two Montenegrin populations of Ukrainian Carpathians]. Visn. Uzhgorod. Ser. Biol. 30, 183-187 (in Ukranian).

Maksymenko, N.V., 2014. Osobennosti landshaftnogo planirovanija territorij raznogo funkcionalnogo naznachenija [Features of landscape planning in areas of different functional purpose]. Minsk. 202 (in Russian).

Maksymenko N.V., Klieshch A.A., 2017. Naprjamku optumizacij pryrodokorystuvannja $v$ invajronmental'noти menedgmenti terytorij lokal'nogo rivnja organizacii dovkillja [Directions for optimization of natural resource use in environmental management for local areas] Dniprop. Univer. bulletin. Geology, geography., 25(2), 81-88 (in Ukranian).

Maksymenko, N.V., Koresheva, O.V., 2014. Analiz konfliktiv pryrodokorystuvannja, jak osnova landshaftnogo planuvannja terytorii Gomil'shans'kogo lisnyctva [Analysis of the nature management conflicts as a basis for landscape planning of Homilshansky forest area]. Visn. L'vivsk, Ser. Geogr. 48, 261-267 (in Ukranian).

Maksymenko, N.V., Voronin, V.O., 2016. Prostorova ocinka radiacijnogo fonu $v$ landshaftah Vasyshhivs'kogo lisnyctva [Evaluation of spatial background radiation in landscapes of Vasyshchivsky forestry]. Biodiversity after the Chernobyl Accident. Part II.: The scientific proceedings of the International network AgroBioNet. - Slovak University of Agriculture in Nitra. 157-161 (in Ukranian).

Nosko, B.S., 1975. K voprosu ob ispol'zovanii agrohimicheskih fonov pri izuchenii jeffektivnosti udobrenij [To a question on the use of agro-chemical backgrounds in the study of fertilizers efficiency]. [Agrochemistry] 6, 76-82 (in Russian).

Rabotnov, . ., 1978. O znachenii pirogennogo faktora dlja formirovanija rastitel'nogo pokrova [On the importance of the pyrogenic factor for the formation of vegetation]. [Botanical Journal]. 63 (11), 1605-1611 (in Russian).

Rodin, L.E., Remezov, N.P., Bazilevich, N.I., 1968. Metodicheskie ukazanija $k$ izucheniju dinamiki $i$ biologicheskogo krugovorota $v$ fitocenozah [Guidelines for the study of the dynamics and biological cycle in phytocenoses]. Nauka, 145 (in Russian).

Sannikova, N.S., 1977. Nizovoj pozhar kak faktor pojavlenija, vyzhivanija i rosta vshodov sosny. Obnaruzhenie $i$ analiz lesnyh pozharov [Ground fire as a factor of the occurrence, survival and growth of pine seedlings. Detection and analysis of forest fires]. Krasnoyarsk. 110-128 (in Russian).

Stolberg, F.V., 2000. Ekologija goroda [Ecology of the city]. 465 (in Russian) 